\title{
SINKRONISASI PERATURAN PERUNDANG- UNDANGAN KETERBUKAAN INFORMASI PUBLIK DALAM SISTEM INFORMASI ADMINISTRASI PERKARA PENGADILAN AGAMA
}

\author{
M. Faried Dzikrullah \\ Lembaga Advokasi dan Layanan Publik (LALP) \\ Email : dfariddzikrullah@gmail.com
}

\begin{abstract}
Abstrak
Pengadilan Agama Kabupaten Malang sebagai salah satu lembaga peradilan yang saat ini sedang mengembangkan implementasi keterbukaan informasi publik, meski pada awal implementasinya sempat menghadapi kendala seiring dengan keterbatasan sumber daya manusia yang berkompeten, disamping karena banyaknya peraturan yang harus diterapkan dalam keterbukaan informasi publik. Karenanya perlu kiranya masing-masing peraturan tersebut dapat diselaraskan dalam implementasinya di melalui sinkronisasi implementasi peraturan perundang-undangan tersebut.
\end{abstract}

Kata kunci: implementasi, sistem informasi, administrasi perkara

\begin{abstract}
The Religious Courts of Malang Regency as one of the judiciary institutions that is currently developing the implementation of openness of public information, although at the beginning of its implementation had faced obstacles in line with the limitations of competent human resources, as well as the number of regulations to be applied in public information disclosure. Therefore it is important that each of these regulations can be adjusted in its implementation through the synchronization of the implementation of the laws and regulations.

Keywords: implementation, information system, administration of things
\end{abstract}

\section{PENDAHULUAN}

Memasuki era globalisasi seperti saat ini maka dunia teknologi dan informasi telah mengalami perkembangan yang sangat pesat dan selalu menghadirkan banyak kemudahan bagi para penggunanya. Dengan adanya perkembangan teknologi dan informasi maka arus informasi semakin cepat, sehingga segala kebutuhan informasi dapat dengan mudah kita dapatkan hanya dalam hitungan detik. Hal ini menjadikan teknologi dan informasi bukan menjadi hal yang tabu di masyarakat, justru menjadi kunci utama dalam menjalankan aktifitas sehari-hari baik di bidang perekonomian dan bisnis, kesehatan, pariwisata, transportasi bahkan peradilan. Oleh karena itu, upaya untuk mengimbangi pesatnya perkembangan teknologi dan informasi harus dilakukan, maka sejalan dengan hal tersebut kita dituntut untuk mengikuti perkembangan yang ada, tidak terkecuali lembaga pemerintahan. 


\section{$\mathcal{H}$ urnal Negara dan Keadilan \\ p-ISSN 2302-7010 e-ISSN 2721-9801}

Pemerintah sebagai penyedia utama layanan publik, dituntut untuk mengikuti perkembangan teknologi dan informasi agar pelayanan publik yang diberikan lebih sederhana, efektif, efisien, dan up to date. Selain itu, mobilitas masyarakat yang semakin tinggi menuntut pemerintah untuk menyediakan pelayanan yang mudah, murah, cepat, efektif dan efisien. Dalam mewujudkan tuntutan tersebut, maka inovasi pelayanan publik yang mengedepankan percepatan dan kemudahan pelayanan mutlak diterapkan oleh pemerintah dengan memanfaatkan berbagai kecanggihan teknologi dan informasi saat ini.

Indonesia adalah Negara hukum ${ }^{1}$, sebagaimana tertuang dalam Pasal 1 Ayat (3) Undang-Undang Dasar Negara Republik Indonesia Tahun 1945, munculnya negara konstitusional pada dasarnya merupakan suatu proses sejarah. Suatu proses sejarah perjuangan bangsa Indonesia menuju negara konstitusional ${ }^{2}$ yang demokrasi ${ }^{3}$. Dengan demikian maka segala sesuatu yang berhubungan dengan penyelenggaraan negara dan pemerintahan harus berlandaskan dan berdasarkan atas hukum.

Negara hukum merupakan suatu negara yang dalam wilayahnya terdapat alat-alat perlengkapan negara, khususnya alat-alat perlengkapan dari pemerintah dalam tindakannya terhadap para warga negara dan dalam hubungannya tidak boleh bertindak sewenang-wenang, melainkan harus memperhatikan peraturanperaturan hukum yang berlaku, dan semua orang dalam hubungan kemasyarakatan harus tunduk pada peraturan-peraturan hukum yang berlaku. ${ }^{4}$

\section{METODE PENELITIAN}

Jenis penelitian yang peneliti lakukan ini adalah penelitian yuridis sosiologis atau peneliian non doktrinal dengan menggunakan pendekatan sosiologis dan yuridis. Dalam penelitian ini sumber data yang digunakan adalah sumer data primer dan sekunder. Teknik pengumpulan data menggunakan teknik wawancara dan dokumentasi. Teknik analisis data menggunakan deskriptif analitis.

\section{PEMBAHASAN}

Salah satu bidang yang mendapatkan jaminan hukum di Indonesia adalah hak masyarakat dalam memperoleh informasi publik, UUD 1945 menjamin adanya hak atas informasi sebagai salah satu hak asasi manusia, sebagaimana dalam Pasal 28F UUD 1945 disebutkan "setiap orang berhak untuk 13.

${ }^{1}$ Sudargo Gautama, Pengertian Tentang Negara Hukum, Alumni, Bandung, 1973, hal.

${ }^{2}$ CF. Strong, Konstitusi-Konstitusi Politik Modern : Kajian Tentang Sejarah dan BentukBentuk Konstitusi Dunia, Nusa Media, Bandung, 2008, hal. 1.

${ }^{3}$ Soehino, Hukum Tata Negara Perkembangan Sistem Demokrasi Di Indonesia, BPFE, Yogyakarta, 2010, hal. 1.

${ }^{4}$ Wikipedia, Negara Hukum, http://id.wikipedia.org/wiki/Negara hukum, diakses pada tanggal 9 September 2017, pukul 08.00 WIB. 


\section{Zurnal Negara dan $\mathcal{X}$ eadilan \\ p-ISSN 2302-7010 e-ISSN 2721-9801}

berkomunikasi dan memperoleh informasi untuk mengembangkan pribadi dan lingkungan sosialnya serta berhak untuk mencari, memperoleh, memiliki, menyimpan, mengolah, dan menyampaikan informasi dengan menggunakan segala jenis saluran yang tersedia".

Jaminan mendapatkan informasi juga tertuang dalam ketentuan Pasal 19 Deklarasi Universal Hak Asasi Manusia (Universal Declaration of Human Rights) Perserikatan Bangsa-Bangsa dimana disebut bahwa "Setiap orang berhak untuk mengeluarkan pendapat danekspresinya; hak ini mencakup kebebasan untuk memiliki pendapat tanpa adanya campur tangan, dan juga hak untuk mencari, menerima, dan menyebarkan informasi dan ide melalui media apapun, dan tak boleh dihalangi".

Penjaminan hak atas informasi sebagai salah satu hak asasi manusia juga ditegaskan lagi dalam Undang-Undang Nomor 39 Tahun 1999 tentang Hak Asasi Manusia sebagai hasil ratifikasi dari Deklarasi Universal Hak Asasi Manusia.

Keterbukaan informasi publik merupakan sarana dalam mengoptimalkan pengawasan publik terhadap penyelenggaraan negara dan badan publik lain serta segala sesuatu yang berakibat pada kepentingan publik. Selain itu, keterbukaan informasi publik ini merupakan ciri khas negara demokrasi yang menjunjung tinggi kedaulatan rakyat untuk mewujudkan penyelenggaraan negara yang baik. ${ }^{5}$ Dan Indonesia merupakan Negara demokrasi tentu harus pula mengedepankan transparansi kinerja pemerintah dalam menjalankan tugas pokok dan fungsinya.

Partisipasi publik dalam proses politik adalah keharusan yang mutlak dipenuhi dalam sebuah pemerintahan yang demokratis. Partisipasi ini bisa mengambil bentuk pemberian dukungan atau penolakan terhadap kebijakan yang diambil oleh badan publik penyelenggara negara ataupun evaluasi terhadap kebijakan tersebut. Untuk itu publik atau warga negara memerlukan sejumlah informasi yang yang berkaitan dengan proses dan substansi kebijakan itu. Tanpa pengetahuan yang memadai, partisipasi publik tidak lebih hanya sebuah seremoni politik yang dilakukan secara reguler. Agar partisipasi publik itu lebih bermakna, maka penyediaan informasi bagi publik harus mencakup agenda politik yang akan dijalankan pemerintah, berbagai kebijakan dan keputusan yang telah dibikin dan dilaksanakan, dan informasi tentang berbagai alternatif kebijakan-baik kebijakan yang dipilih maupun tidak dipilih.

Pemerintahan yang terbuka berisi badan-badan publik yang terbuka kepada masyarakat dalam rangka pelayanan. Dengan membuka akses publik terhadap informasi diharapkan semua badan publik termotivasi untuk bertanggung jawab dan berorientasi pada pelayanan rakyat dengan sebaik-baiknya. Keterbukaan informasi bukan hanya menguntungkan bagi masyarakat tetapi juga penyelenggara pemerintahan, baik eksekutif dan legislatif, maupun yudikatif. Jika informasi publik tersedia dengan cukup, maka pimpinan lembaga penyelenggara pemerintahan dalam arti luas bisa memanfaatkan pengawasan oleh masyarakat untuk meningkatkan kinerja dan gerak organisasi hingga ke daerah-daerah. Toby Mendel menyatakan bahwa : Keterbukaan informasi publik merupakan salah satu fondasi dalam mewujudkan tata kelola pemerintahan yang baik (good governance), dan kebebasan memperoleh informasi (public access to information)

${ }^{5}$ http://puspiptek.ristek.go.id/media.php?module=detail berita\&id=1763-pelaksanaan-uuno-14-tahun-2008-tentang-keterbukaan-informasi-publik-permasalahan-dan-solusinya.html diakses pada tanggal 9 September 2017, pukul 13.12 WIB. 


\section{$\mathcal{H}$ urnal Negara dan Keadilan \\ p-ISSN 2302-7010 e-ISSN 2721-9801}

merupakan salah satu prasyarat untuk menciptakan pemerintahan terbuka (open government). ${ }^{6}$

Pemerintahan terbuka adalah penyelenggaraan pemerintahan yang transparan, terbuka, dan partisipatoris. Semakin terbuka penyelenggaraan negara untuk diawasi publik, maka penyelenggaraan negara tersebut makin dapat dipertanggungjawabkan. Pada tataran badan usaha, konsep pengelolaan yang baik (good corporate governance) juga sudah dianggap sebagai suatu kebutuhan. Tata kelola yang baik memiliki sejumlah indikator antara lain keterbukaan, partisipasi, akuntabilitas, efektivitas, dan koherensi. ${ }^{7}$

Menurut Mas Achmad Santosa, pemerintahan yang terbuka mensyaratkan adanya jaminan atas lima hal, yaitu : Pertama, hak untuk memantau perilaku pejabat publik dalam menjalankan peran publiknya; Kedua, hak untuk memperoleh informasi; Ketiga, hak untuk terlibat dan berpartisipasi dalam proses pembentukan kebijakan publik; Keempat, kebebasan berekspresi yang antara lain diwujudkan dalam kebebasan pers; dan Kelima, hak untuk mengajukan keberatan terhadap penolakan atas keempat hak terdahulu. ${ }^{8}$

Pada masyarakat modern, kebutuhan atas informasi semakin banyak dan semakin urgen. Informasi menjadi kebutuhan dasar dalam pengambilan keputusan-keputusan personal dan sosial. Perkembangan teknologi komunikasi turut mendorong perkembangan informasi. Setiap detik, informasi terus menyebar dari satu tempat ke tempat lain dengan cepat akibat perkembangan teknologi komunikasi. ${ }^{9}$ Setiap hari kita disuguhi informasi dari belahan dunia yang berbeda nyaris pada saat bersamaan. Batas-batas antar negara seolah menjadi hilang (borderless world) akibat pesatnya perkembangan informasi. Tidak ada satu pun negara yang bisa secara mutlak menghambat pesatnya laju arus informasi.

Ketertutupan dalam menjalankan penyelenggaraan negara akan mengakibatkan penyalahgunaan dalam bentuk korupsi, kolusi dan nepotisme $(\mathrm{KKN})$, di setiap tingkatan pemerintahan (eksekutif, legislatif dan yudikatif). Kasus-kasus seperti penyimpangan dana Perpajakan, dana BLBI, dan kasus korupsi merupakan bukti dari tidak adanya keterbukaan dalam birokrasi pemerintahan. Koalisi Untuk Kebebasan Informasi menyebut dua hal penting untuk memberantas KKN di Indonesia yang harus segera dibangun adalah penguatan sistem penegakan hukum untuk memberikan efek jera dan mewujudkan pemerintahan Indonesia sebagai pemerintahan terbuka dan transparan.

Kebebasan informasi atau jaminan atas akses publik terhadap informasi (public access to information), sistem negara yang demokratis (democratic state) dan tata pemerintahan yang baik (good governance) merupakan tiga konsep yang

${ }^{6}$ Toby Mendel, Kebebasan Memperoleh Informasi, Sebuah Survei Perbandingan Hukum, UNESCO, Jakarta, 2004, hal. 31.

${ }^{7}$ Kristian Erdianto, dkk. Implementasi Hak Atas Informasi Publik : Sebuah Kajian dari Tiga Badan Publik Indonesia. Edisi Pertama. Centre for Law and Democracy dan Yayasan Dua Puluh Delapan, Jakarta, 2012, hal. 45.

${ }^{8}$ Mas Achmad Santosa, Good Governance dan Hukum Lingkungan, ICEL, Jakarta, 2001, hal. 22.

${ }^{9}$ Komisi Informasi Pusat Republik Indonesia dan Indonesian Center for Environmental Law (ICEL), Anotasi Undang-Undang Nomor 14 Tahun 2008 tentang Keterbukaan Informasi Publik, Edisi Pertama. Yayasan Tifa, Jakarta, 2009. hal. 3. 


\section{Zurnal Negara dan $\mathcal{X}$ eadilan \\ p-ISSN 2302-7010 e-ISSN 2721-9801}

saling terkait satu dengan lainnya. ${ }^{10}$ Dengan adanya kebebasan informasi membuat masyarakat dapat mengontrol setiap langkah dan kebijakan yang diambil oleh Pemerintah. Dalam negara demokrasi, penyelenggaraan kekuasaan harus dapat dipertanggungjawabkan kembali kepada rakyat. Adapun tolak ukur untuk menilai apakah tindakan pemerintah itu sejalan dengan negara hukum atau tidak dapat diketahui dengan menggunakan asas-asas umum pemerintahan yang layak. $^{11}$

Komitmen untuk mewujudkan pemerintahan yang transparan tersebut, diwujudkan dengan diundangkannya Undang-Undang Nomor 14 Tahun 2008 tentang Keterbukaan Informasi Publik. Undang-Undang ini baru diberlakukan sejak tahun 2010 atau dua tahun setelah disahkan. Dalam undang-undang tersebut mewajibkan lembaga ekskutif, legislatif dan hukum maupun lembaga pemerintah lainnya yang didanai oleh Anggaran Pendapatan dan Belanja Negara (APBN) maupun Anggaran Pendapatan dan Belanja Daerah (APBD) untuk menyediakan informasi terkait kebijakan, kegiatan dan keuangan kepada rakyat.

Gagasan ideal dalam undang-undang tersebut jika tidak terlaksana dengan baik, maka akan menjadi tulisan di atas kertas belaka. Masalah implementasi mencakup sikap pemerintah pusat maupun pemerintah daerah yang cenderung segan menyediakan informasi dan kurang responsif terhadap undang-undang baru, sementara masyarakat sipil kekurangan pengetahuan dan kesadaran tentang halhal yang disebut di atas.

Setiap badan publik sebagaimana diamanatkan dalam Pasal 7 Ayat (3) Undang-Undang wajib membangun dan mengembangkan sistem informasi dan dokumentasi untuk mengelola informasi publik secara baik dan efisien sehingga layanan informasi dapat memberikan akses dengan mudah. Bahkan lebih lanjut setiap badan publik perlu melakukan pengelolaan informasi dan dokumentasi yang dapat menjamin penyediaan informasi yang mudah, cermat, cepat dan akurat. Dari segi praktis, sebagai lembaga yang fungsi dan tugas pokoknya berhubungan dengan penyelenggaraan negara, setiap Badan Publik tidak lepas dari pengawasan rakyat, baik dalam konteks individu, kelompok orang, badan hukum, ataupun badan publik lainnya. Pengelolaan dan penyelenggaraan keterbukaan informasi publik secara baik dan benar dapat memberikan beberapa keuntungan praktis bagi Badan Publik dan kepada bangsa secara keseluruhan. ${ }^{12}$

Adapun yang maksud keterbukaan informasi publik dalam tataran implementasinya adalah mempersiapkan perangkat, sarana dan pra sarana. Pada tataran ini adanya perubahan paradigma mengenai informasi, data dan layanan menjadi tantangan tersendiri bagi badan publik dalam pelaksanaan UndangUndang Nomor 14 Tahun 2008, karena luasnya cakupan tugas pokok dan fungsi. Meskipun secara normatif hak dan kewajiban pemohon informasi, pengguna informasi dan badan publik telah tergambar dalam Undang-Undang Nomor 14 Tahun 2008. Ada beberapa aspek badan publik yang memerlukan perhatian, yakni perlunya dibentuk sistem untuk memisahkan dan memilah informasi publik yang

${ }^{10}$ Ignatius Haryanto, Apa Itu Kebebasan Memperoleh Informasi?, Lembaga Studi Pers dan Pembangunan (LSPP), Jakarta, 2005, hal. 13.

${ }^{11}$ Ridwan HR, Hukum Administrasi Negara, Rajawali Pers, Jakarta, 2010, hal. 242.

12 Dessy Eko Prayitno, dkk., Melaksanakan Undang-Undang Nomor 14 Tahun 2008 tentang Keterbukaan Informasi Publik, ICEL, Jakarta, 2010, hal. 4. 


\section{$\mathcal{H}$ urnal Negara dan Keadilan \\ p-ISSN 2302-7010 e-ISSN 2721-9801}

dapat diakses dan yang dikecualikan, pendokumentasian, katalogisasi semua informasi publik, mekanisme pelayanan informasi baik secara internal, interkoneksi antar lembaga/badan publik dan pihak eksternal, serta persiapan terkait infrastruktur, baik berupa teknologi informasi, sumber daya manusia dan sistem. $^{13}$

Tersirat maksud tersebut di atas bahwa ketersediaan instrumen pendukung pengelolaan informasi dan dokumentasi merupakan kebutuhan yang mutlak menjadi perhatian penting bagi setiap badan publik dan perlu dipersiapkan dalam kegiatan pra implementasi undang-undang tersebut, tanpa terkecuali oleh lembaga yudikatif dibawah Mahkamah Agung Republik Indonesia.

Transaparansi peradilan bagi Mahkamah Agung saat ini bukan saja menjadi kebutuhan publik tetapi juga kebutuhan seluruh warga badan peradilan. Dengan adanya transparansi peradilan, secara perlahan akan terjadi penguatan akuntabilitas dan profesionalisme serta integritas warga peradilan. ${ }^{14}$ Keterbukaan informasi yang efektif dan efisien merupakan bagian dari komitmen Mahkamah Agung dalam rangka reformasi birokrasi. Bahkan jauh sebelum lahirnya UndangUndang Nomor 14 Tahun 2008 tentang Keterbukaan Informasi Publik dan Peraturan Komisi Informasi Nomor 1 Tahun 2010 tentang Standar Layanan Informasi Publik tersebut, Mahkamah Agung sudah lebih dahulu mengimplementasikan adanya keterbukaan informasi publik, sebagaimana dituangkan dalam Surat Keputusan Ketua Mahkamah Agung RI Nomor : 144/KMA/VIII/2007 tentang Keterbukaan Informasi di Pengadilan.

Komitmen lembaga peradilan di bawah Mahkamah Agung untuk mewujudkan pelaksanaan tugas dan pelayanan informasi yang efektif dan efisien sebagaimana amanat ketentuan dalam peraturan peraturan perundang-undangan tersebut, diwujudkan dengan merevisi Surat Keputusan Ketua Mahkamah Agung RI Nomor: 144/KMA/VIII/2007 tentang Keterbukaan Informasi di Pengadilan, menjadi Surat Keputusan Ketua Mahkamah Agung RI Nomor: 1144/KMA/SK/2011 tentang Pedoman Pelayanan Informasi di Pengadilan. Surat keputusan ini merupakan pedoman teknis dalam pelaksanaan pelayanan informasi yang sesuai dengan tugas, fungsi dan organisasi pengadilan.

Inovasi pelayanan publik harus mendapat dukungan dari berbagai stakeholder termasuk sumber daya manusia yang mampu memberikan pelayanan dengan baik. Hal tersebut mendorong pemerintah untuk meningkatkan pelayanan publik kepada masyarakat di semua lini tanpa terkecuali sistem peradilan yang termasuk dalam Lembaga Yudikatif. Pengadilan agama sebagai salah satu dari bagian dari Lembaga Yudikatif yang berada di bawah naungan Mahkamah Agung telah melakukan beberapa agenda reformasi termasuk dalam pemanfaatan teknologi dan informasi. Salah satunya diwujudkan dalam bentuk Sistem Informasi Administrasi Perkara Pengadilan Agama (SIADPA) yang saat ini bernama SIADPAPlus yang secara resmi digunakan di seluruh Indonesia sejak

13 Arief Mudatsir Mandan, Sekilas tentang UU KIP, makalah dipresentasikan pada Seminar UU KIP Departemen Hukum dan HAM, http://www.depkumham.go.id, diakses pada tanggal 23 Nopember 2017, pukul 13.00 WIB.

14 Ridwan Mansyur, Keterbukaan Informasi di Pengadilan pada Penerapan Sistem Penelusuran Perkara, https://www.mahkamahagung.go.id/images/news/ KETERBUKAAN \%20_INFORMASI_PADA_PENGADILAN.pdf, diakses pada tanggal 9 Juni 2017, pukul 06.30 WIB. 


\section{Hurnal Negara dan $\mathcal{X}$ eadilan \\ p-ISSN 2302-7010 e-ISSN 2721-9801}

tahun 2005 hingga sekarang. SIADPA lahir karena selama ini pola yang digunakan di pengadilan agama yaitu pola Bindalmin (Pembinaan dan Pengendalian Administrasi Pengadilan) belum mampu menjawab permasalahan penyampaian informasi seputar perkara yang sedang ditangani oleh pengadilan agama, seperti informasi terkait sejauh mana proses perkara serta lamanya pembuatan pelaporan perkara. Fenomena meningkatnya kesadaran masyarakat akan penyelesaian perkara di pengadilan agama tersebut, menjadikan pengadilan agama membutuhkan manajemen perkara yang dapat diandalkan dan efisien dengan memanfaatkan perkembangan teknologi dan informasi berupa SIADPA. Sistem Informasi Administrasi Perkara Pengadilan Agama (SIADPAPlus) pertama kali diterapkan oleh Pengadilan Agama Kabupaten Malang yang kemudian di akuisisi oleh Badan Peradilan Agama (Badilag) Berawal dari tuntutan masyarakat mengenai penyampaian informasi perkara serta jumlah perkara yang tinggi di Pengadilan Kabupaten Malang yang mencapai sekitar 400 perkara setiap bulan. Tingginya perkara yang masuk tidak diimbangi oleh ketersediaan sumber daya manusia dan penerapan sistem manual tanpa memanfaatkan teknologi informasi, sehingga pilihan untuk bekerja di luar jam kantor bagi pegawai Pengadilan Agama Kabupaten Malang tidak dapat dihindarkan untuk mengurangi penumpukan perkara. SIADPA muncul sebagai sarana untuk membenahi sistem administrasi perkara dalam rangka meningkatkan percepatan penyelesaian perkara, akuntabilitas, efektif serta transparansi.

SIADPAPlus di Pengadilan Agama Kabupaten Malang terintegrasi dengan berbagai aplikasi unggulan, salah satunya dengan aplikasi Audio to Text Recording (ATR). Berdasarkan hasil kompetisi inovasi pelayanan publik peradilan pada Tahun 2015, aplikasi Audio to Text Recording (ATR) berhasil menjadi pemenang sekaligus sebagai juara favorit berdasarkan vote dari masyarakat.

Aplikasi Audio to Text Recording merupakan aplikasi yang berfungsi untuk mengubah suara menjadi teks secara otomatis yang digunakan Pengadilan Agama Kabupaten Malang untuk merekam jalannya persidangan. Hal ini tentu dapat menjadi salah satu sarana mempercepat proses penyelesaian berkas perkara serta berdampak langsung terutama bagi hakim dan panitera atau panitera pengganti. Bagi hakim dengan adanya aplikasi Audio to Text Recorder (ATR) proses pembuatan putusan bisa lebih cepat, sedangkan bagi panitera atau panitera pengganti penggunaan ATR bisa mempercepat proses pembuatan Berita Acara Persidangan (BAP). Adapun penggunaan aplikasi ATR dilaksanakan dalam beberapa tahap, setelah semua tahap penggunaan ATR telah selesai maka langkah selanjutnya yaitu membuka aplikasi SIADPAPlus untuk mengisi Berita Acara Persidangan dengan memasukkan nomor perkara terlebih dahulu (sumber: dokumen Pengadilan Agama Kabupaten Malang).

Latar belakang melakukan inovasi ini lantaran jumlah perkara yang masuk pada tahun 2014 ke Pengadilan Agama Kabupaten Malang sebanyak 8.700 perkara. Sementara itu, Pengadilan Agama Kabupaten Malang hanya memiliki tenaga hakim yang berjumlah 15 orang (termasuk ketua dan wakil ketua) dan tenaga panitera atau panitera pengganti dengan jumlah 14 orang termasuk panitera, wakil panitera, dan panitera muda.

Dari beberapa peraturan perundang-undangan yang mengatur tentang keterbukaan informasi publik di Pengadilan tersebut di atas, telah terlihat terdapat 


\section{Jurnal Negara dan $\mathcal{X}$ eadilan \\ p-ISSN 2302-7010 e-ISSN 2721-9801}

potensi ketidaksinkronan antara peraturan yang satu dengan yang lainnya karenanya sangatlah penting dilakukan sinkronisasi dalam pengimplementasian peraturan tersebut, hal ini sangat penting karena sangat berpengaruh pada berbagai perubahan yang sudah barang tentu membawa dampak yang penting dalam peningkatan kinerja guna menuju lembaga peradilan yang agung.

Pengadilan Agama Kabupaten Malang sebagai salah satu lembaga peradilan di bawah Mahkamah Agung saat ini sedang mengembangkan implementasi keterbukaan informasi publik, meski pada awal implementasinya sempat menemui kendala seiring dengan keterbatasan sumber daya manusia yang kompeten, disamping karena banyaknya peraturan yang harus diterapkan dalam keterbukaan informasi publik. ${ }^{15}$ Karenanya penulis berpendapat perlu kiranya masing-masing peraturan tersebut dapat diselaraskan dalam implementasinya di Pengadilan Agama Kabupaten Malang melalui sinkronisasi implementasi peraturan perundang-undangan tersebut.

\section{PENUTUP}

Sinkronisasi Surat Keputusan Ketua Mahkamah Agung RI Nomor 1144/KMA/SK/I/2011 dengan Undang-Undang Nomor 14 Tahun 2008 secara umum telah mencapai taraf yang baik, namun masih terdapat muatan yang tidak sesuai dengan ketentuan Undang-Undang, seperti penunjukan PPID pada pengadilan tingkat pertama dan banding serta satuan kerja eseolan I Mahkamah Agung tidak memenuhi kualifikasi sebagai pejabat yang membidangi informasi publik dan memiliki kompetensi di bidang pengelolaan informasi dan dokumentasi. Implementasi sinkronisasi peraturan perundang-undangan tentang keterbukaan informasi publik di Pengadilan Agama Kabupaten Malang dapat dikatakan secara umum berjalan dengan baik, baik dari segi substansi, struktur maupun budaya hukumnya.

\section{Buku}

\section{DAFTAR PUSTAKA}

CF. Strong, 2008, Konstitusi-Konstitusi Politik Modern : Kajian Tentang Sejarah dan Bentuk-Bentuk Konstitusi Dunia, Bandung: Nusa Media.

Dessy Eko Prayitno, dkk., 2010, Melaksanakan Undang-Undang Nomor 14 Tahun 2008 tentang Keterbukaan Informasi Publik, Jakarta: ICEL.

Ignatius Haryanto, 2005, Apa Itu Kebebasan Memperoleh Informasi?, Jakarta: Lembaga Studi Pers dan Pembangunan (LSPP).

Komisi Informasi Pusat Republik Indonesia dan Indonesian Center for Environmental Law (ICEL), 2009. Anotasi Undang-Undang Nomor 14 Tahun 2008 tentang Keterbukaan Informasi Publik, Edisi Pertama. Jakarta: Yayasan Tifa, Jakarta. 


\section{Hurnal Negara dan $\mathcal{X}$ eadilan \\ p-ISSN 2302-7010 e-ISSN 2721-9801}

Kristian Erdianto, dkk. 2012, Implementasi Hak Atas Informasi Publik : Sebuah Kajian dari Tiga Badan Publik Indonesia. Edisi Pertama. Jakarta: Centre for Law and Democracy dan Yayasan Dua Puluh Delapan.

Mas Achmad Santosa, 2001, Good Governance dan Hukum Lingkungan, Jakarta: ICEL

Ridwan HR, 2010, Hukum Administrasi Negara, Jakarta: Rajawali Pers.

Soehino, 2010, Hukum Tata Negara Perkembangan Sistem Demokrasi Di Indonesia, Yogyakarta: BPFE.

Sudargo Gautama, 1973, Pengertian Tentang Negara Hukum, Bandung: Alumni.

Toby Mendel, 2004, Kebebasan Memperoleh Informasi, Sebuah Survei Perbandingan Hukum, Jakarta: UNESCO

\section{Internet}

Arief Mudatsir Mandan, Sekilas tentang UU KIP, makalah dipresentasikan pada Seminar UU KIP Departemen Hukum dan HAM, http://www.depkumham.go.id, diakses pada tanggal 23 Nopember 2017, pukul 13.00 WIB.

Http://puspiptek.ristek.go.id/media.php?module=detail berita\&id=1763pelaksanaan-uu-no-14-tahun-2008-tentang-keterbukaan-informasi-publikpermasalahan-dan-solusinya.html diakses pada tanggal 9 September 2017, pukul 13.12 WIB.

Ridwan Mansyur, Keterbukaan Informasi di Pengadilan pada Penerapan Sistem Penelusuran Perkara, https://www.mahkamahagung.go.id/images/news/ KETERBUKAAN \%20_INFORMASI_PADA_PENGADILAN.pdf, diakses pada tanggal 9 Juni 2017, pukul 06.30 WIB.

Wikipedia, Negara Hukum, http://id.wikipedia.org/wiki/Negara_hukum, diakses pada tanggal 9 September 2017, pukul 08.00 WIB. 